\title{
Childhood Large Cell Lymphoma
}

National Cancer Institute

\section{Source}

National Cancer Institute. Childhood Large Cell Lymphoma. NCI Thesaurus. Code C8310.

A large cell lymphoma occurring in childhood. 